\title{
THE ROLE OF EMOTIONAL INTELLIGENCE AND SOCIAL SUPPORT: PREDICTING THE STUDENTS' LEARNING ACHIEVEMENT IMPROVEMENT
}

\author{
Mujidin*, Ajeng Rizky Ardhia Pramesti, Husnul Khotimah Rustam \\ *Correspondent Author
}

\author{
Mujidin \\ Universitas Ahmad Dahlan \\ Jalan Kapas No 9 Semaki, Umbulharjo, \\ Yogyakarta \\ Indonesia \\ Email: mujidin.230760@gmail.com \\ Ajeng Rizky Ardhia Pramesti \\ Universitas Ahmad Dahlan \\ Jalan Kapas No. 9 Semaki, Umbulharjo, \\ Yogyakarta \\ Indonesia \\ Email: ajengpramesti28@gmail.com \\ Husnul Khotimah Rustam \\ Universitas Ahmad Dahlan \\ Jalan Kapas No 9 Semaki, Umbulharjo, \\ Yogyakarta \\ Indonesia \\ Email: husnulkhotimahr6@gmail.com
}

\begin{abstract}
The purpose of this study was to determine the role of emotional intelligence and social support with learning achievement in class XI students of SMA Negeri 1 Bengkulu Selatan. This study is a non-experimental study with a correlational design to determine the effect of emotion regulation on students' learning achievement. This study proves two hypotheses, first, there is a significant emotional intelligence with an increase in student achievement. Second, there is a significant relationship between social support and an increase in student achievement. This study collected data from 89 students using a random technique from the population of SMA Negeri 1 Bengkulu Selatan. The data collection instruments used were emotional intelligence questionnaires, social support questionnaires and student achievement documents. The analysis used is more specific, namely simple linear regression analysis. The results showed that there was a significant relationship between emotional intelligence and academic achievement with an rxy value of 0.283 plus a $p$ value of 0.013 . Furthermore, second hypotheses, there is a significant relationship between social support and an increase in student achievement was rejected with a $p$ value of 0.064 and clarified with an rxy value of 0.212 , which means that there is no relationship between social support and increased learning achievement. The results of this study can be used as a reference to determine the right way to deal with students' academic and problems with guidance and counseling that is fun to maximize emotional intelligence, social support and student achievement
\end{abstract}

Keywords: emotional intelligence, social support, student learning achievement 


\title{
11| PSIKOPEDAGOGIA
}

\author{
JURNAL BIMBINGAN DAN KONSELING
}

Vol.10, No.1, June 2021

\section{INTRODUCTION}

The purpose of any learning process is to demonstrate the changes that the school wants. Individuals must have the readiness to achieve these learning objectives. Readiness starts from physical and psychological conditions. This readiness is necessary because it can determine the quality of the process and student learning achievement (Mulyani, 2013). Thus, learning achievement is not only measured by knowledge, but it is also measured by cognitive, affective, and psychomotor, which is manifested in the form of values called achievement (Mulyaningsih, 2014). Through school, students learn various things that aim to pursue achievement. Through learning achievement, a student can determine the progress that he or she has achieved in learning (Thaib, 2013).

The results of Mulyani's research (2013) showed that there was an improvement in student achievement by as much as $81.01 \%$. This figure was considered quite good and was influenced by many factors, such as general basic abilities, talents, motivation, study habits, and environment. Students completed each exam with satisfactory results. This success was due to the readiness of the students themselves in facing each exam starting from the easiest to the most difficult levels. In contrast to Mulyani's result, Mulyaningsih (2014) conducted her research at SMK Negeri 5 Surakarta. The results showed that $7 \%$ of students had low learning achievement on their test scores.

A similar condition was also supported by Thahir and Hidriyanti (2014), who stated that 89 students of the Al-Utrujiyyah Islamic Boarding School experienced an impairment score in al-Qur'an-Hadith, moral beliefs, and figh subjects whose scores were below the KKM. The factor that influenced this problem was that the students were influenced by social media and handphones, so they limited their time to study. Students spent more time playing with gadgets than reading the school materials or doing their assignments. Nevertheless, there were still many students who got some achievement in school by bringing the good name of the school and themselves into the competition. The victory felt by students could not be separated from supporting factors such as the emergence of emotional intelligence and social support. Sunarti (2018) examined the correlation of emotional intelligence with learning achievement. The results were proven to be significant and contributed as much as $2.28 \%$ to learning achievement. Students who had high emotional intelligence were declared more successful because it was easier and stronger to remember their lessons. This research was also supported by Hulu and Minauli (2013), who showed that 76 respondents had good emotional intelligence. This means that these students had a good ability to manage and control emotions so that they could direct and motivate themselves in achieving learning achievements in everyday life.

Every student has a relationship with other people. This relationship can increase students' enthusiasm for learning. A study proved that social support affected the improvement of students' achievement by as much as $4.7 \%$. Patty, Wijono, and Setiawan (2016) explained that they had received social support, which could make their self-control more stable so that students' achievement was also high.

This study aims to determine the role of emotional intelligence and social support on students' achievement. The results of this study can be used as a reference for guidance and counseling teachers in determining the right way to overcome their students' academic achievement problems by maximizing emotional intelligence and social support.

\section{RESEARCH METHOD}

This study was a nonexperimental study with a correlational design. This study correlated emotional intelligence and social support with the students' learning achievement. The study aimed to determine the contributions of the two variables, namely, emotional intelligence and social support, to students' learning achievement. The sample included 78 students in SMA Negeri 1 Bengkulu Selatan, especially in the XI MIPA 1, XI IPS 1, and XI IPS 2 classes. The 
sampling technique used a probability sampling technique with cluster random sampling. This technique was performed by taking a sample from the group and then being selected randomly as a representative of the population. The data collected were compiled based on a scale made by the researcher. First, the researcher used the emotional intelligence scale from Goleman (2012), namely, recognizing self-emotions, managing emotions, self-motivation, recognizing other people's emotions, and social skills. Furthermore, the social support scale was developed based on Sarafino's aspects (2011), including emotional support and appreciation, instrumental support, information, and friendship. Learning achievement was measured from the student report cards evaluation in the second semester. The analysis used was more specific, namely, simple linear regression analysis.

\section{RESULTS AND DISCUSSIONS}

This study showed satisfactory results. The first results could be seen from descriptive data and statistical analysis. The results of the data analysis are shown in Tables 1 and 2 . Then, the partial correlation between $X 1$ and $\mathrm{X} 2$ and $\mathrm{Y}$ is shown in table 3 , while table 4 gives the results of multiple linear regression correlations.

Table 1

Emotional Intelligence

\begin{tabular}{llll}
\hline Interval & Category & Frequency & Percentage \\
\hline $\begin{array}{l}84,11266 \leq \\
X\end{array}$ & high & 58 & 74,36 \\
$79,46254 \leq$ & moderate & 13 & 16,66 \\
$X$ & & & \\
$<84,11266$ & & & \\
$\quad X$ & low & 7 & 8,98 \\
$<79,46254$ & & & \\
Total & & 78 & $100 \%$ \\
\hline
\end{tabular}

As shown in table 1, seven students had a low level of emotional intelligence. Fifty-eight students had a high level of emotional intelligence. These results indicated a correlation with the ease with which students manage their emotions. The next table was the result of social support.
Table 2

Social Support

\begin{tabular}{llll}
\hline Interval & Category & Frequency & Percentage \\
\hline $\begin{array}{l}84,11266 \leq \\
X\end{array}$ & high & 0 & 0 \\
$\begin{array}{l}79,46254 \leq \\
X\end{array}$ & Moderate & 5 & $6,41 \%$ \\
$\begin{array}{l}<84,11266 \\
X\end{array}$ & & & \\
$\begin{array}{l}<79,46254 \\
\text { Total }\end{array}$ & Low & 73 & $93,59 \%$ \\
\hline
\end{tabular}

The social support scores in table 2 vary widely. Starting from the medium category of $6.41 \%$ with a frequency of five students. Furthermore, the low category included seventy-three students, representing $93.59 \%$ of the sample. The social support category was only low to moderate. Furthermore, learning achievement will be shown in the table below.

Table 3

Learning Achievement

\begin{tabular}{llll}
\hline Interval & Category & Frequency & Percentage \\
\hline $84,11266 \leq$ & High & 14 & $17,95 \%$ \\
$\mathrm{X}$ & & & \\
$79,46254 \leq$ & Moderate & 54 & $69,23 \%$ \\
$\mathrm{X}$ & & & \\
$<84,11266$ & & & \\
$\quad \mathrm{X}$ & Low & 10 & $12,82 \%$ \\
$\begin{array}{l}<79,46254 \\
\text { Total }\end{array}$ & & 78 & $100 \%$ \\
\hline
\end{tabular}

From table 3, some students showed high, medium, and low categories in their learning achievement. The high category was fourteen students, the medium category was fifty-four students, and the low category was ten students.

From table 4 , the result of the correlation coefficient (rxy) between emotional intelligence and learning achievement was considered significant $(0.013)$. The result of the correlation coefficient (rxy) between social support and learning achievement was not significant because the $p$ value was 0.064 and the rxy value was 0.212 . 


\section{3 | PSIKOPEDAGOGIA}

JURNAL BIMBINGAN DAN KONSELING

Vol.10, No.1, June 2021

Table 4

Coefficient of Determination Analysis

\begin{tabular}{|c|c|c|c|c|c|}
\hline & & & $\begin{array}{l}\text { Emotional } \\
\text { Intelligence }\end{array}$ & $\begin{array}{l}\text { Social } \\
\text { Support }\end{array}$ & $\begin{array}{l}\text { Learning } \\
\text { Achievement }\end{array}$ \\
\hline \multirow[t]{7}{*}{$\begin{array}{l}\text { Pear } \\
\text { son }\end{array}$} & $\begin{array}{l}\text { Emotional } \\
\text { Intelligence }\end{array}$ & $\begin{array}{l}\text { Correlation } \\
\text { Coefficient } \\
\text { sig (1- } \\
\text { tailed) N }\end{array}$ & 1,000 & 0,380 & 0,013 \\
\hline & & & 78 & 78 & 78 \\
\hline & $\begin{array}{l}\text { Social } \\
\text { Support }\end{array}$ & $\begin{array}{l}\text { Correlation } \\
\text { Coefficient } \\
\text { sig (1- } \\
\text { tailed) N }\end{array}$ & 0,074 & 1,000 & 0,212 \\
\hline & & & 78 & 78 & 78 \\
\hline & $\begin{array}{l}\text { Learning } \\
\text { Achievemen }\end{array}$ & $\begin{array}{l}\text { Correlation } \\
\text { Coefficient }\end{array}$ & 0,013 & 0,064 & 1,000 \\
\hline & $t$ & $\begin{array}{l}\text { sig (1- } \\
\text { tailed) N }\end{array}$ & 0,212 & 0,074 & \\
\hline & & & 78 & 78 & 78 \\
\hline
\end{tabular}

This research model was related to the regression correlation, which means that the results of the research were positively correlated, so the conclusion was that there was a significant relationship between emotional intelligence and social support on the students' achievement. Based on Halimi, AIShammari, and Navarro (2020), their research results confirmed that emotional intelligence was an important factor related to learning achievement, especially on the individual's internal emotions. Thaib (2013) added that emotional intelligence was an important factor that must be possessed by students to achieve better learning achievement in school and prepared them to face the real world, and it was suggested to the schools, especially teachers, to add emotional intelligence in delivering material and involve students' emotions in the learning process. Effective and enjoyable learning was part of the supporting factors for increasing students' achievement in the classroom. Ansong, Okumu, Bowel, and Eisensmith (2017) found that emotional factors were accepted in a balanced manner in their research hypothesis. Emotional involvement could be characterized when the students were in the class. They felt happy. Ansong,
Okumu, Bowel, and Eisensmith et al. (2017) asked the respondents some questions, including when they do something in class, they are interested in the class; it is a fun class; they enjoy learning something new; and when they are doing something in class, they are actively involved.

Emotions are often involved in life, including in students (Sharma, 2017). Students put forward their emotional feelings for learning, memory, making decisions, learning styles, success in school, or interacting with the social environment (Rai \& Khanal, 2017; More, 2020). This expression was seen from Preeti's research result, which showed that with emotional intelligence, students could understand relevant information from their environment. In addition, students who had high emotional intelligence and academic goals were achieved (Preeti, 2013; Mursaleen \& Munaf, 2016). The result could be achieved with a strong push from emotional intelligence, as evidenced by the results of Hanafi and Noor (2016). Emotional intelligence made individuals more active and willing to achieve and succeed in learning. Individuals who had a good level of emotional intelligence were predicted to encourage students to improve their achievements (Pamungkas, 2013).

The idea of Bakhshi, Gupta, and Singh (2016) stated that emotional intelligence was positively correlated with academic achievement. The value of $r=0.23$ indicated that the minor hypothesis in the study was accepted. Bakhshi, Gupta, and Singh explained that although the coefficient value was small, the meaning of the relationship between emotional intelligence and student academic achievement remained linear. The previous statement that emotional intelligence embodies student success was agreed upon by Bimayu, Kristiawan, and Fitriani (2020). The results of Bimayu, Kristiawan, and Fitriani's research (2020) explained that good and controlled emotional intelligence also increased learning achievement. If emotional intelligence was poor and uncontrolled, student learning achievement also decreased. The findings of previous experts strengthen researchers' beliefs about emotional 
intelligence, especially on academic achievement. Researchers found strong evidence of this phenomenon based on Jenaabadi, Shahidi, Elhamifar, and Khademi's research results (2015). Emotional intelligence in several studies was considered to be able to predict student achievement, for example, improving students' academic motivation (Naik \& Kiran, 2018) and time management, being able to achieve clear goals, and communicating decisively with others (Koç, 2019).

Emotional intelligence has a larger estimate and effect than social support. From this study, it was found that there was no relationship between social support and learning achievement. The results of this study were different from those of previous studies. Kusrini and Prihartanti (2014) stated that there was a relationship between social support and English learning achievement. This could be explained by the fact that social support was information received from others that the individual was loved, cared for, valued, and it was part of a communication network and needs each other obtained from parents, husbands, loved ones, relatives, friends, relationships, and society so that good support would be able to encourage them to carry out activities, namely, learning. Social support from teachers and peers also played an important role in student achievement. For students, the teacher was someone who had authority other than their parents in terms of education. The peer group was a group that had a special closeness to each other so that they could influence each other.

Ansong et al. (2017) classified social support into 3 groups, namely, parents, peers, and teachers. Today's learning is virtual, so individuals need more energy, be more sensitive, and be more easily stressed. One of the supports that must be given from parents was the fulfillment of nutritional insurance, basic needs more attention, and not making individuals weak.

Acceptance of the null hypothesis indicated that the lack of social support in students was a phenomenon and made others more aware. This was an empirically constructed description and prediction (Conlin, Kuo, \& Hallinen, 2019). The replication carried out by Michelson and Morley's researchers obtained the null hypothesis (Conlin, Kuo, \& Hallinen, 2019). They found that the great potential for developing sophisticated tools to measure the relative motion between Earth and aluminiferous was not appreciated and meaningful because it was more suitable when used on other celestial objects.

The number of samples and the sampling method were important components of significant research results (Cohen, 2019). In this study, the number of samples was still lacking and did not represent the entire population. Furthermore, the cluster sampling method was not considered to be an appropriate method to track the distribution of samples with higher average academic achievement. The significance of the $p$ value was not a pure indicator of how much the influence of the emotional intelligence variable or social support variable was. The $p$ value provided an overview of research data but was not the only measuring tool to describe the effect size of the respondent's personality or behavior interpretation (Corotto, 2020).

This study concentrated on the relationship between social support and learning achievement, and the results of this study were supported by Maglica, Ribičić, and Ljubetić (2020). The results of the study found that there was no significant relationship between emotional intelligence and social support with learning success and achievement in school. Many factors inhibited the decline in student academic achievement, including changes in the current learning situation through the internet or virtual conferences. As a result, without direct and face-to-face guidance, students were required to become independent learners to learn, such as taking resources from the internet to fulfill school assignments, but students did not understand the material (Teeraputon \& Nuankaew, 2020).

\section{CONCLUSION}

It can be concluded that there is a significant relationship between emotional 


\title{
15| PSIKOPEDAGOGIA
}

\author{
JURNAL BIMBINGAN DAN KONSELING
}

Vol.10, No.1, June 2021

intelligence and social support on the students' learning achievement in the eleventh-grade students of SMA N 1 Bengkulu Selatan. There is a significant positive relationship between emotional intelligence and learning achievement among eleventh-grade students of SMA N 1 Bengkulu Selatan. This means that students who have higher emotional intelligence will have higher learning achievements. On the other hand, students who have lower emotional intelligence will have lower learning achievement. Furthermore, there is no significant relationship between social support and learning achievement. To improve students' learning achievement, schools need teachers and parents to pay attention to students' emotional development and always create a comfortable and happy atmosphere so that students are more motivated to pursue their learning achievements. The results of this study can be used as a reference to determine the right way to handle students' psychological and academic problems by providing pleasant guidance and counseling to maximize emotional intelligence, social support, and student achievement.

\section{ACKNOWLEDGMENT}

The researcher thanks all parties who have helped the completion of this research, related parties such as Ahmad Dahlan Yogyakarta University, Principal of SMA Negeri 1 Bengkulu Selatan, students of SMA Negeri 1 Bengkulu Selatan, and the respondents who have contributed, suggestions, material, and nonmaterial support.

\section{REFERENCE}

Ansong, D., Okumu, M., Bowel, G. L., Walker, A. M., \& Eisensmith, S. R. (2017). The Role Of Parent, Classmate, and Teacher Support in Student Engagement: Evidence From Ghana. International Journal of Educational Development, 54 (1). 51-58.

Bakhshi, A., Gupta, K., \& Singh, D. (2016). Emotional Intelligence in Relation to Academic Achievement of Secondary School Students. 3 (3). 71-73.

Bimayu, W., Kristiawan, M., \& Fitriani, Y. (2020). The Effect of Emotional Intelligence, Student's Motivation
Toward Student's Achievement. International Journal of Progressive Sciences and Technologies, 20 (1). 616.

Cohen, M., P. (2019). Why Not An Interval Null Hypothesis. Journal of Data Science. 17 (2). 383-390.

Conlin, L., D, Kuo, E., \& Hallinen, N., R. (2019). How Null Results Can Be Significant For Physics Education Research. Physical Review Physics Education Research, 15 (1), 1-13.

Corotto, F. (2020). Your Null Hypothesis Must Be False: Test It Anyway. Georgia Journal of Science. 78 (3), 1-6.

Halimi, F., AlShammari, I., \& Navarro, C. (2020). Emotional Intelligence and Academic Achievement In Higher Education. Journal of Applied Research in Higher Education. Vol. 13 No. 2, pp. 485-503.

Hanafi, Z., \& Noor, F. (2016). Relationship Between Emotional Intelligence and Academic Achievement in Emerging Adults: A Systematic Review. International Journal of Academic Research in Business and Social Sciences, 6(6), 268-290.

Hulu, T., \& Minauli, I. (2013). Hubungan Antara Kecerdasan Emosi dan Efikasi Diri dengan Prestasi Belajar. Analitika: Jurnal Magister Psikologi UMA, 5(2), 50-56.

Jenaabadi, H., Shadidi, R., Elhamifar A., \& Khademih, H. (2015). Examine The Relationship of Emotional Intelligence and Creativity With Academic Achievement of Second Period High School Students. Journal of Neuroscience, 5 (4), 275-281.

Koç, S. E. (2019). The Relationship Between Emotional Intelligence, Self-Directed Learning Readiness and Achievement. International Online Journal of Education and Teaching (IOJET), 6 (3). 672-688

Kusrini, W., \& Prihartanti, N. (2014). Relationship Between Social Support and Self-Confidence With The English Achievement of Class Viii Students of SMP Negeri 6 Boyolali". Jurnal Penelitian Humaniora, 15 (2), 131-140.

Maglica, T., Ribičić, A., \& Ljubetić, M. (2020). Social and Emotional Competencies and Academic Achievement In Elementary School Students". Originalni Naučni Rad. 29 (1), 25-48.

More, S. (2020). Difference In Self, Emotional Intelligence and Academic 
Achievement Of CBSE School Students on Demographic Variables. International Journal of Arts and Social Science, 3 (3), 313-322.

Mulyani, D. (2013). Hubungan Kesiapan Belajar Siswa dengan Prestasi Belajar. Konselor Jurnal IImiah Konseling, 2(1). 27-31.

Mulyaningsih, I. E. (2014). Pengaruh Interaksi Sosial Keluarga, Motivasi Belajar, dan Kemandirian Belajar Terhadap Prestasi Belajar. Jurnal Pendidikan dan Kebudayaan, 20(4), 441-451.

Mursaleen, M., \& Munaf, S. (2016). Associations of Intellectual Ability With Emotional Intelligence, Academic Achievement and Aggression of Adolescents". Journal of Basic \& Applied Sciences, 12 (1). 344-350.

Naik, D., \& Kiran, D. A. (2018). Emotional Intelligence and Achievement Motivation Among College Students". Indian Journal of Health and Wellbeing, $9(1), 86-88$.

Pamungkas, R. 2013. Pengaruh Kecerdasan Emosional terhadap Hasil Belajar pada Siswa Kelas V SD Se-Kecamatan Prembun. Jurnal Kalam Cendekia. Vol.5(5): 1-5

Patty, S., Wijono, S., \& Setiawan, A. (2016). Hubungan Dukungan Sosial Teman Sebaya, Kontrol Diri, Dan Jenis Kelamin Dengan Prestasi Belajar Siswa Di SMA Kristen YPKPM Ambon. Psikodimensia, 15(2), 204-235.

Preeti, B. (2013). Role Of Emotional Intelligence For Academic Achievement For Students. Research Journal of Educational Sciences. 1 (1). 8-12.

Rai, D., \& Khanal, Y. K. (2017). Emotional Intelligence And Emotional Maturity And Their Relationship With Academic Achievement Of College Students In Sikkim. International Journal Of Education And Psychological Research. 6 (2). 1-5.

Sarafino, E. P. (2011). Health Psychology: Biopsychosocial Interactions, 7th edition. Amerika Serikat: John Wiley \& Sons, Inc.

Sharma, R. (2017). Emotional Intelligence, Social Intelligence and Achievement Motivation Of Arts And Science Students". International Journal of Research in all Subjects in Multi Languages, 5 (7).
Sunarti, I. (2019). Pengaruh Kecerdasan Emosi, Efikasi Diri dan Motivasi Belajar Terhadap Prestasi Belajar Mahasiswa Pendidikan Ekonomi Uniku (Survei Pada Mahasiswa Semester Ganjil 2017-2018 Pendidikan Ekonomi Universitas Kuningan. Equilibrium: Jurnal Penelitian Pendidikan dan Ekonomi, 15(02), 16-33.

Teeraputon, D., \& Nuankaew, P. (2020). Attitude and Learning Styles in Different Academic Achievement Of Tertiary Students. Universal Journal of Educational Research, 8 (1), 61786184.

Thahir, A., \& Hidriyanti, B. (2014). Pengaruh Bimbingan Belajar Terhadap Prestasi Belajar Siswa Pondok Pesantren Madrasah Aliyah Al-Utrujiyyah kota Karang Bandar Lampung. KONSELI: Jurnal Bimbingan dan Konseling (EJournal), 1(2), 55-66.

Thaib, E, N. (2013). Relationship Between Learning Achievement And Emotional Intelligence. Jurnal IImiah DIDAKTIKA, 13 (2), 384-399. 